\title{
The Recycling Efficiency of Li-ion EV batteries according to the European Commission Regulation, and the relation with the End-of-Life Vehicles Directive recycling rate
}

\author{
Dr. Jan Tytgat ${ }^{1}$ \\ ${ }^{1}$ Umicore, Broekstraat 31,BE-1000 Brussels, jan.tytgat@umicore.com
}

\begin{abstract}
In Europe, batteries from electric vehicles are subject to the EC Directive 2006/66/EC (Batteries Directive). This Directive regulates the end-of-life management and sets targets on the recycling efficiency. The concept of battery recycling efficiency goes beyond the recycling target of the End-of-Life Vehicles directive. The paper describes the meaning of the recycling efficiency and illustrates how it is calculated in the case of Li-ion battery recycling according to the Umicore battery recycling process.
\end{abstract}

Keywords: EU, lithium battery, recycling, regulation,

\section{Introduction}

In the European Union, the end of life management of batteries is regulated by $\mathrm{EC}$ Directive 2006/66/EC [1], further referred to as the Batteries Directive (BD). The main objective of the $\mathrm{BD}$ is 'to minimise the negative impact of batteries and accumulators and waste batteries and accumulators on the environment', including a contribution to the EU resource efficiency policy (explained in the official Q\&A [2]). It is anticipated that the minimum 'recycling efficiency' (RE) as specified in the BD, would guarantee the environmental and resource efficiency objectives.

The target RE-value depends on the battery chemistry. It is set to $65 \%$ for lead-acid batteries, to $75 \%$ for nickel-cadmium batteries and to $50 \%$ for all 'other batteries'.

At the time when the BD was developed and published in 2006, the vast majority of 'other' batteries were primary $\mathrm{Zn}$-based batteries. The RE-target of $50 \%$ for the category of 'other batteries', was mainly based on these battery chemistries. Since the publication of the BD, the relative importance of advanced battery chemistries, and especially Li-ion batteries, has grown enormously and the applications where these batteries are used are changing. Today, we are at the eve of the breakthrough of e-mobility, which is almost fully based on Li-ion battery technology. So, it is the right time for a reflection on the RE-target for Li-ion batteries and to analyse whether the actual applicable RE-target corresponds with the initial objective of the $\mathrm{BD}$, i.e. 'minimizing the negative impact of batteries on the environment'.

In this article, the RE-calculation methodology formulated in Commission Regulation (EU) $\mathrm{N}^{\circ}$ 493/2012 [3], will be explained and applied to Liion batteries from $(\mathrm{H}) \mathrm{EV}$ 's and recycled according to the Umicore process. When several interpretations are possible, the instruction of the "Working Document on Draft Guidelines" [4] (further referred to as 'Draft Guidelines') will be applied, for as far as an answer is provided.

Propulsion batteries in electric vehicles are part of the vehicle and so subject to the End of Life of Vehicles directive (ELV) [5]. But as they are 
batteries, they are also subject to the BD. This relation will also be discussed.

\section{The Recycling Efficiency concept in EU legislation}

The BD is the first (and so far the only) European directive that includes the concept of 'recycling efficiency': it includes all process efficiencies (in terms of the ratio between qualified recycling output fraction and weight of recycling input fraction) until the final recycling step; this means: until products are obtained that are considered as 'end of waste' or until the products have a well defined purpose, without undergoing further treatment. A Regulation is published to detail the calculation methodology [3] and a Guidance document how to interpret the Regulation will be published in the course of 2013. At the moment of publication of this article, a Working Document on Draft Guidelines circulates amongst the stakeholders [4]. In this article, the stipulations of this Draft Guidelines will be applied and discussed

The BD's RE cannot be compared with the 'recovery rate' of the WEEE-directive [6]. The WEEE recycling rate is the weight ratio of the WEEE-fraction that goes to the recovery/recycling plant divided by the weight of WEEE collected. So, it doesn't include the efficiency of the recovery/recycling facility.

A comparison between the recycling and recovery rates of the ELV and the RE of the BD is not possible as the ELV rates are based on another concept. The ELV rates refer to the weight of the vehicle and dismantled or depolluted parts, whereas the BD's RE is a process efficiency indicator, including all subsequent process steps.

According to article 1 of Commission Decision 2005/293/EC on the monitoring of reuse/recovery/recycling targets of the ELV directive [5], the reuse/recycling/recovery rates of the ELV should include the materials from depollution and for materials entering further treatment, the actually achieved recovery is taken into account. Although this could be interpreted that the efficiency of all further steps after the shredder and depollution operations have to be included (as in the BD's recycling efficiency), but the official reporting sheet (table 1 of Annex of Commission Decision 2005/293/EC [5]) only refers to 'materials from de-pollution and dismantling'. This illustrates that the ELV recycling and recovery rates calculation ends after depollution and dismantling. Another difference between ELV and BD is that the ELV recognizes the difficulty to recycle plastics and synthetic fibres and contrary to the $\mathrm{BD}$, the ELV includes energy recovery targets to cope with these materials.

In order to develop a coherent calculation methodology for batteries RE, specific Regulations and Guidelines had to be published after intensive stakeholder consultations.

\section{The Umicore Battery Recycling process}

The Umicore battery recycling process is specifically designed to reach a high recycling efficiency for new generation rechargeable batteries (Li-ion and NiMH). The process can also be used for recycling of other complex materials. Large industrial batteries, like batteries from hybrid and full electric cars, are first dismantled in a dedicated dismantling line in Hanau (Germany) or in Maxton, NC (USA). Most of the dismantled parts can be recycled locally, but the smelting operations for cells and modules are performed in Hoboken (Belgium).

The process is described at the company's website [8] and graphically summarized in Figure 1.

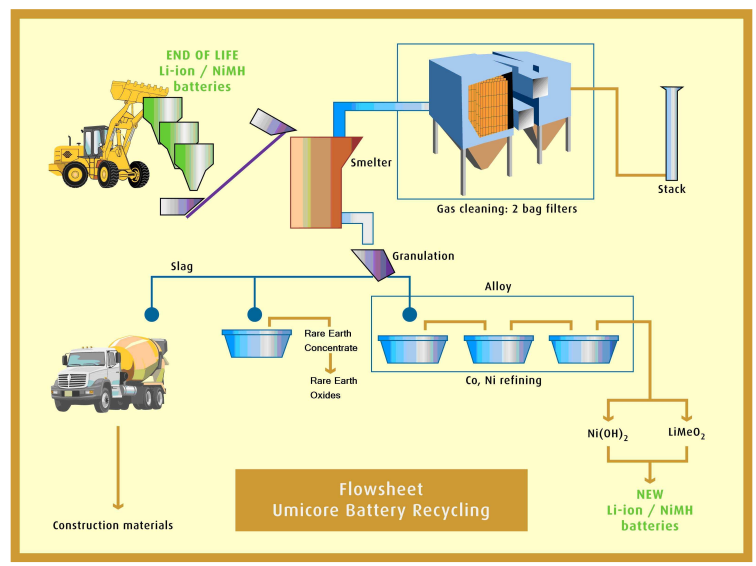

Figure 1: Umicore battery recycling flow sheet

\section{The management of end-of- life vehicles and their batteries}

The management of end-of-life vehicles is regulated by the ELV-Directive. The ELV includes the concept of 'de-pollution'. The depollution 
includes the removal of batteries. According to the Waste Framework Directive [9], specific rules for particular instances, ..., may be laid down by means of individual Directives. As the BD is more specific on batteries than the ELV, and the $\mathrm{BD}$ explicitly stipulates that vehicle batteries are subject to the $\mathrm{BD}$, there is no doubt that $\mathrm{EV}$ batteries have to be recycled according to the $\mathrm{BD}$ and the Regulation. This has been confirmed by Commissioner Potočnik on behalf of the Commission in an answer to Parliamentary question E-3855/2010 from Marielle De Sarnez (ALDE) [10].

For the BD, the definition of 'vehicle' is broader than for the ELV-directive. It includes all kind of vehicles, amongst others: two-wheelers, wheel chairs, automatic transport vehicles.

The predecessor of the actual BD (council directive (91/157/EEC), which was valid at the time when the ELV was published (2000), did not contain any recycling target. So, when the ELV was published, it was logic to include the recycling and recovery rate of the batteries in the overall ELV recycling and recovery rate calculations. Also other 'de-polluted' materials are included in the ELV recycling and recovery rate calculations. However, with the new BD (published in 2006), there are clear targets for batteries.

As illustrated in $\S 2$, the battery RE is a more difficult concept, that needs a specific Regulation and Guidelines to explain. It goes beyond the ELV recycling target and includes the efficiency of all operations until a recyclate is obtained that can be used without further treatment. Practical criteria for the end of the recycling process are given in the Regulation.

On the other hand, the BD doesn't set targets or reporting duties on energy recovery, as the ELV does. Consequently, the official battery recycling efficiency figure doesn't contribute to the ELV recovery target.

This means that the consolidation of the batteries $\mathrm{RE}$ in the recycling rate for ELV reporting is not straightforward. Provided that the batteries are recycled and reported in compliancy with the $\mathrm{BD}$, it would be appropriate that batteries could be reported as 'completely recycled' for ELV reporting.

According to the ELV directive, the battery has to be removed. For the car recycling industry, supported by the Draft Guidelines [4], the (H)EV battery is the full battery assembly (top of Figure 2) and not just the battery cells or modules (right side of Figure 2. The battery disassembly is considered as a specialists' job, to be performed in dedicated workshops and not by the car recycling companies. Also transport to the battery recycling plant would be safer when the battery assembly is not dismantled. The Draft Guidelines [4], that gives clarifications on the interpretation of the Regulation, confirms that the full EV battery assembly has to be considered as a 'battery: 'Since this (note: the $(\mathrm{H}) \mathrm{EV}$ battery assembly) is a battery and not a battery pack, the rate of 50\% should be achieved on the whole EV battery and not only on the cells'. This is an important clarification, because it means that not only the electrochemically active parts (cells and modules) are subject to the RE-calculation, but also parts such as bus bars, cooling circuit, battery management system (BMS) and the protective housing (left side of Figure 2).

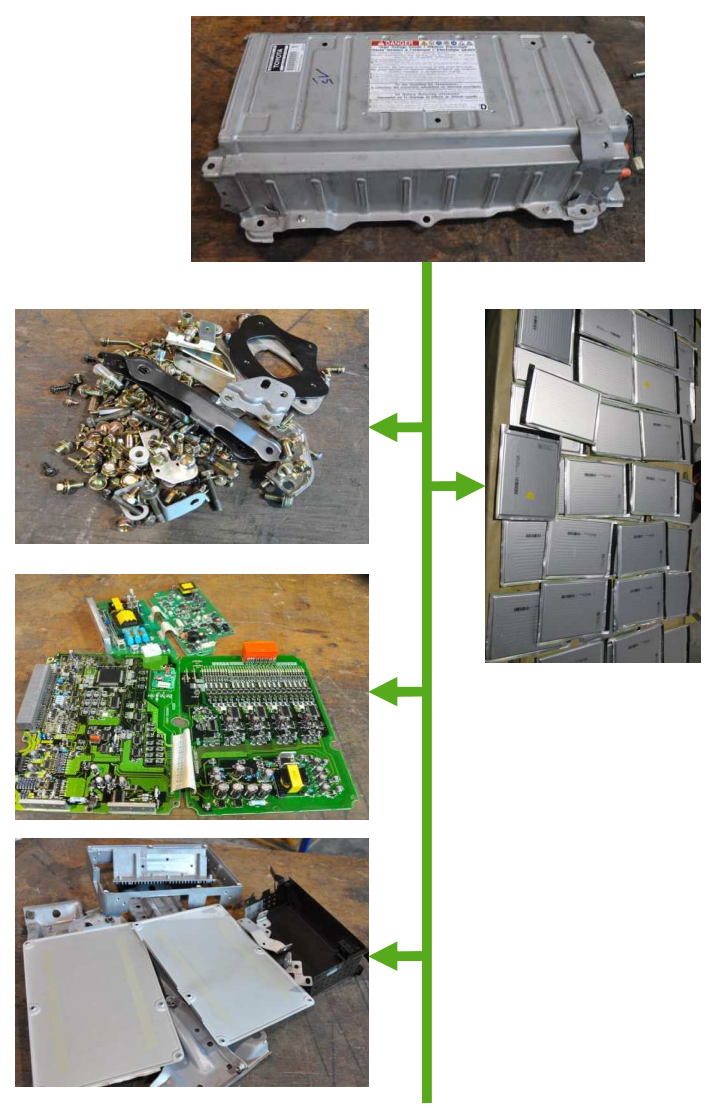

Figure 2: typical EV battery, disassembled in modules (containing cells) and other materials 
Table 1: calculation of RE on module level

\begin{tabular}{|lcccccccccccc|}
\hline modules & $\mathrm{Al}$ & $\mathrm{Li}$ & $\mathrm{Ni}$ & $\mathrm{Mn}$ & $\mathrm{Co}$ & $\mathrm{O}$ & $\mathrm{Cu}$ & $\mathrm{C}$ & $\mathrm{F}$ & $\mathrm{P}$ & $\mathrm{H}$ & \\
\hline $\begin{array}{l}\text { element composition } \\
\text { input fraction (\%) }\end{array}$ & 12 & 3 & 5 & 12 & 5 & 17 & 10 & 30 & 3 & 1 & 2 & 100 \\
$\begin{array}{l}\text { recycling efficiency } \\
\text { per element (\%) }\end{array}$ & 100 & 100 & 100 & 100 & 100 & 50 & 100 & 0 & 0 & 100 & 0 & \\
\hline $\begin{array}{l}\text { recycled in output } \\
\text { fraction (\%) }\end{array}$ & 12 & 3 & 5 & 12 & 5 & 8,5 & 10 & 0 & 0 & 1 & 0 & $\begin{array}{c}\text { RE (rounded) } \\
=57 \%\end{array}$ \\
\hline
\end{tabular}

Obviously, battery cells and modules are also subject to the BD recycling target. Cells and modules can be delivered to the recycler e.g. from a battery refurbishment/repair centre, where defective cells and modules are replaced.

Current EV battery recycling processes start with dismantling of the battery assembly in its components, as illustrated in Figure 2. This is needed because the full assembly cannot enter in a metallurgical process as such (physical and chemical restriction with today's processes), and there is no need for metallurgical processing for several of the dismantled components such as pure metals and plastics.

\section{Calculation of the Recycling Efficiency (RE)}

According to the Regulation [4], the recycling efficiency of a recycling process is calculated as follows:

$$
\mathrm{RE}=\left(\Sigma \mathrm{m}_{\text {output }} \times 100\right) / \mathrm{m}_{\text {input }}[\text { mass } \%]
$$

where:

- $\mathrm{RE}=$ calculated recycling efficiency of a recycling process for the purpose of Article 12(4) of Directive 2006/66/EC [1] [in mass \%];

- $\mathrm{m}_{\text {output }}=$ the mass of output fractions accounting for recycling per calendar year;

- $\quad \mathrm{m}_{\text {input }}=$ the mass of input fractions entering the battery recycling process per calendar year.

From the definition, it is clear that the RE is an overall mass balance. It doesn't specify efficiencies on element level. The recycling of non-hazardous, non-valuable elements (like $\mathrm{O}$ ) is accounted the same way as critical elements (like Co).

The numerical examples in the next paragraphs are 'typical, rounded' values, and illustrative only. They do not reflect the composition of a commercial EV battery, nor do they represent a market average. There is a broad range of battery chemistries and material compositions. The figures given below are just a possible composition. When material variations would have a significant impact on the calculation results, it will be illustrated.

In most EV batteries, several cells are embedded in a coated aluminium pouch or aluminium box to form a module. In the Umicore process, the modules are not further dismantled. Further dismantling to cell level would become too expensive and is not necessary for the smelting operations. The weight of the module housing is negligible compared to the cell weight; in the calculation below, recycling efficiency will be calculated on module level and not on cell level.

\subsection{Typical battery composition}

A typical high level breakdown of two EV batteries is given in Figure 3. Most of today's EV batteries have a metal protective casing. In these batteries, cells represent about $60 \%$ of the total battery weight. The metals fraction contains stainless steel from the casing, aluminium from cooling conducts, copper bus bars. This fraction can easily be sorted for further treatment in dedicated facilities. The plastic fraction contains different types of plastics. Further sorting is possible for larger parts. Plastic fractions that cannot be recycled can be recovered for energy production, but for the $\mathrm{BD}$, this energy recovery is not reported. The mixed fraction contains structures with metal and plastic compounds that are difficult to sort (e.g. printed circuit board). Most of the metals can be recycled and the plastics are used as source of energy in the metals recycling process.

Some EV batteries have a synthetic fibre casing, which made them lighter and consequently, the vehicle becomes more energy efficient in the use phase. Due to the lighter casing material, the cell fraction and the plastic fraction (including the synthetic fibre) become relatively larger. The metal fraction of the non-cell fraction becomes smaller. 
An overview of the chemical composition of a typical EV battery module mixture is given in Table 2.

Table 2: Typical figures elemental composition on module level (\%)

\begin{tabular}{|c|c|c|c|c|c|c|c|c|c|c|}
\hline $\mathrm{Al}$ & $\mathrm{Li}$ & $\mathrm{Ni}$ & $\mathrm{Mn}$ & $\mathrm{Co}$ & $\mathrm{O}$ & $\mathrm{Cu}$ & $\mathrm{C}$ & $\mathrm{F}$ & $\mathrm{P}$ & $\mathrm{H}$ \\
\hline 12 & 3 & 5 & 12 & 5 & 17 & 10 & 30 & 3 & 1 & 2 \\
\hline
\end{tabular}

The $\mathrm{Al}$ is mostly from the $\mathrm{Al}$ cathode foil and module housing, but part of the $\mathrm{Al}$ could also come from active cathode material. Al from foil and module housing is present in its metallic form, whereas $\mathrm{Al}$ in cathode material is present as an oxide. $\mathrm{Li}, \mathrm{Ni}, \mathrm{Mn}, \mathrm{Co}$ and $\mathrm{O}$ are from the active cathode material $\left(\mathrm{LiNi}_{\mathrm{x}} \mathrm{Mn}_{\mathrm{y}} \mathrm{Co}_{\mathrm{Z}} \mathrm{O}_{2}\right.$ with $x+y+z=1$, some $\mathrm{Li}$ is also from the electrolyte salt $\left(\mathrm{LiPF}_{6}\right)$ and some of the $\mathrm{O}$ is from the organic solvent (typically propylene carbonatediethyl carbonate). The anode foil is $\mathrm{Cu}$ and $\mathrm{C}$ is the anode material. Some of the $\mathrm{C}$ is also from the solvent and the separator. $\mathrm{P}$ and $\mathrm{H}$ are respectively from the electrolyte salt and from the organic materials.
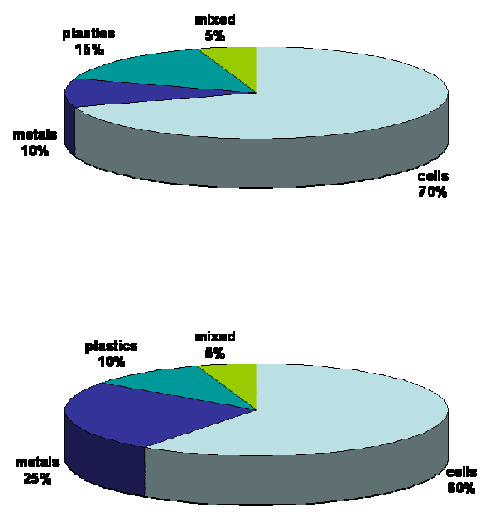

Figure 3: high level breakdown of two typical EV battery assemblies. Top: battery with a metal housing; bottom: battery with synthetic fibre housing

\subsection{Input fraction}

The input fraction is the full battery weight, excluding the water fraction. Some batteries contain a dedicated cooling circuit. The dissolved cooling agent (e.g. ethylene glycol) should be included in the input fraction, but the water should not. All other compounds and elements have to be considered: not only the valuable metals, but also elements such as $\mathrm{O}$ from the cathode metal oxide compound, $\mathrm{F}$ and $\mathrm{P}$ from the electrolyte salt, the graphite anode material, separator, solvent...

In a typical EV-battery recycling scheme, the EV batteries are first dismantled, generating following fractions:

- Metals, further sorted into steel, copper and aluminium

- Plastics

- Mixed materials: metals and plastics that are difficult to separate (e.g. printed circuit boards)

- Electrochemical parts: modules and cells (dismantling level dependent on recycling scheme)

According to the Draft Guidelines, those parts that can easily be dismantled, belong to the input fraction as well (left side of Figure 2), although in actual recycling processes, they are treated separately from the electrochemical parts (right side of Figure 2).

\subsection{Output fractions}

Only the output fractions 'accounting for recycling' may be included (also called 'qualified output fractions'). The basic philosophy is that an output fraction can only be accounted for recycling if there is a market for it and that it is commonly used for a specific purpose. As long as the output fraction needs further treatment before it is suited for an application, it is not accounted for recycling. This means that the efficiency of all operations, until the end of recycling has been achieved, must be included. The first recycler (i.e. the recycling company that performs the first actions to dismantle the battery assembly is its different components), has to acquire an in depth insight of the treatment of all fractions that are further treated by subsequent recyclers. He has to apply the rules of the Regulation to each of the separated fractions and is responsible for the agglomerated RE.

In the next sections, the qualified output fractions of each of the input fractions will be discussed

\subsubsection{Discussion on the non-electrochemical parts}

The sorted pure metals are further treated by dedicated metal smelters to convert them into tradable formats (shape, quality). As this is a 
further treatment to make the metals suited for an application, the efficiency of these smelter processes has to be included in the $\mathrm{RE}$ calculations. In the numerical example, it will be assumed to be $98 \%$.

In theory, the plastic could be further sorted according to their chemistries, to allow recycling. However, in practice, only the larger plastic parts are sorted out and recycled, whereas other plastic parts are used for energy recovery. So, it doesn't account for recycling efficiency. In the numerical examples, all plastics and organic compounds will be considered as recovered for energy.

The mixed materials can be treated in a metals recycling smelter, focusing on $\mathrm{Cu}$ recycling. The organic compounds will be used as smelter fuel and so be considered as recovered. In the numerical example, it will be assumed that the metal content (typically about $30 \%$ ) is fully recycled.

\subsubsection{Discussion on the electrochemical parts}

The electrochemical parts, if treated in Umicore's UHT smelter, will generate two main fractions that are considered as recycled products:

- a metal alloy fraction, containing $\mathrm{Ni}, \mathrm{Co}$, $\mathrm{Cu}$.

- a metal oxide fraction, containing $\mathrm{Al}, \mathrm{Li}$, $\mathrm{Mn}, \mathrm{O}, \mathrm{P}$

Both fractions needs some after treatment to make them suited for an application. As the losses during these after-treatment operations are negligible, the efficiency is considered as $100 \%$ (except for $\mathrm{O}$, see further).

The process also produces emissions $\left(\mathrm{CO}_{2}\right.$ and $\mathrm{H}_{2} \mathrm{O}$ ). According to the Regulation, $\mathrm{C}$ can be accounted as recycled provided that it acts as a reducing agent during the process and if this has been approved by an independent scientific body. In the Umicore process, the $\mathrm{C}$ is mainly used as an energy source and to a lower extent as a reducing agent. For the sake of simplicity, in the numerical example, no $\mathrm{C}$ will be accounted for recycling. The oxygen in the emission is partly originating from the batteries and partially added to the smelter to control the process. The battery oxygen that leaves the process as an emission cannot be accounted as recycled. A stoichiometric calculation is needed to determine the amount of recycled oxygen (in the metal oxide fraction). For the numerical example, the battery-O recycled in the metal oxide fraction is estimated at $50 \%$.

Fluorine is collected in the off gas cleaning installation. This $\mathrm{F}$ could be recycled as well, but today the critical mass to invest in a F-recycling unit is not yet reached.

The recycling efficiency on module level is calculated in Table 1.

\subsubsection{Agglomerated RE calculation and discussion on battery level}

As every battery fraction has its own partial RE, a weighted overall RE has to be calculated (Table 3 ). Although the recycling processes are the same for both typical batteries (as illustrated in figure 3), and the battery module composition is the same, due to the larger portion of the plastics fraction, the $\mathrm{RE}$ of EV batteries with synthetic fibre casing is significantly lower.

The Guidance document is not a legally binding document. This means that (national) authorities could give another interpretation to the definition of 'pack' and 'battery'. If the authorities would decide that EV battery assemblies are packs, then the reported value would be the partial RE of the modules. According to the reporting template (annex to the Regulation), the recycling of the nonbattery pack materials have to be reported separately, without impacting the RE. This way, the reported RE would be independent from the selected casing material.

As outlined before, it is quite possible that the EV batteries will be assessed for a second application. Battery refurbishment centres could develop test protocols to identify the bad performing cells or

Table 3: calculation of a consolidated RE on battery level (calculated for a $100 \mathrm{~kg}$ battery)

\begin{tabular}{|l|c|c|c|c|c|c|}
\hline \multirow{2}{*}{ RE estimation } & \multicolumn{3}{|c|}{ steel casing } & \multicolumn{3}{c|}{ synthetic fibre casing } \\
\cline { 2 - 7 } & $\begin{array}{c}\text { input fraction } \\
(\mathrm{kg})\end{array}$ & $\begin{array}{c}\text { partial } \\
\mathrm{RE}\end{array}$ & $\begin{array}{c}\text { output fraction } \\
(\mathrm{kg})\end{array}$ & $\begin{array}{c}\text { input fraction } \\
(\mathrm{kg})\end{array}$ & $\begin{array}{c}\text { partial } \\
\mathrm{RE}\end{array}$ & $\begin{array}{c}\text { output fraction } \\
(\mathrm{kg})\end{array}$ \\
\hline modules & 60 & $\mathbf{5 7 \%}$ & 33,9 & 70 & $\mathbf{5 7 \%}$ & 39,6 \\
metals & 25 & $98 \%$ & 24,5 & 10 & $98 \%$ & 9,8 \\
plastics & 10 & $0 \%$ & 0 & 15 & $0 \%$ & 0 \\
mixed & 5 & $30 \%$ & 1,5 & 5 & $30 \%$ & 1,5 \\
\hline RE (rounded) & & & $60 \%$ & & & $51 \%$ \\
\hline
\end{tabular}


modules. The rejected cells are also subject to the $\mathrm{BD}$, as can be concluded from the Guidance document.

Notice that the battery cells contain about $50 \%$ non metal elements $(\mathrm{C}, \mathrm{O}, \mathrm{F}, \mathrm{P}, \mathrm{H})$, which are not commonly recycled. Because the Umicore recyclates contain a significant $\mathrm{O}$ content, the $\mathrm{RE}$ raises above $50 \%$. Metallurgical processes that don't recycle the battery-oxygen or graphite, risk not reaching the $50 \%$ target on module level.

Does the $50 \%$ target correspond to the initial target of the $\mathrm{BD}$, i.e. avoiding dissemination of hazardous compounds in nature and contribute to the resource efficiency? The most hazardous compounds in Li-ion batteries are the electrolyte (solvent and salt) and the heavy metals ( $\mathrm{Ni}, \mathrm{Co}$, $\mathrm{Mn})$.

- The electrolyte solvent is destroyed in the process and safely converted into $\mathrm{CO}_{2}$ and $\mathrm{H}_{2} \mathrm{O}$. Although contributing to the $\mathrm{BD}$ objectives, this doesn't contribute at all to the RE.

- Regarding the contribution to the resource efficiency, the total concentration of metals and 'critical' raw material elements (as defined in the Report of the Ad-hoc Working Group on defining critical raw materials [11]) is about 45 to $55 \%$ (depending on synthetic fibre or steel casing). The balance, also ranging between 45 and $55 \%$, are elements of very low resource efficiency concern: C, O, H, P. This means that a large part of the RE could be obtained by recycling these irrelevant elements, which is in some cases easier than recycling of metals. E.g. suppose that water that is formed during a recycling process is captured and used for a purpose instead of being released in nature (after purification). That water would be accounted in the RE, although it doesn't contribute at all to the BD objectives.

\subsubsection{Reporting and discussion on vehicle level}

The Regulation also specifies the reporting modalities. The RE reporting obligation is at the $1^{\text {st }}$ battery recycler, who needs to agglomerate the efficiencies of all sub processes into one figure. This means that he should acquire knowledge until the end of recycling. The end of recycling is when all fractions are a final waste, an emission or a qualified output fraction. An output fraction is qualified when the recyclate can be used as such for the same or another application.

The most essential aspects of the reporting are (i) that it is based on yearly basis; and (ii) on process level. This means that all different types of batteries that are treated in the same process generate only one RE-figure per year. Referring to $\S$ 5.3.3: suppose that both battery types are processed in the same process and that $90 \%(\mathrm{w} / \mathrm{w})$ of the recycled batteries would have a steel casing and $10 \%$ would have a synthetic fibre casing, then the reported figure would be $0.9 \times 59.9 \%+0.1 \times$ $50.85 \%=59.00 \%$. If other batteries would be processed together with the EV batteries, the weighted average RE has to include the other batteries as well.

The RE has to be reported to the national authorities, directly by the $1^{\text {st }}$ recycler. The BD doesn't foresee a reporting line to the ELV compliancy schemes. Most EV battery recyclers will also treat, in the same process, other $\mathrm{Li}$-ion batteries (portable, or from other industrial applications). A hypothetical 'pure' EV battery RE can be calculated, but the official RE figure should include all batteries recycled in the same process during one year.

The BD doesn't specify (energy) recovery targets or reporting duties. So, it can be expected that the energy recovery of battery materials will not accurately be reported to the ELV compliance organisations.

Eurostat and the European Commission are not aware of any European member state that has established reporting obligations to EV battery recyclers [12]. For the time being, it is not clear if and how the EV-battery RE has to be reported to the ELV compliance organisations.

Another aspect in the end-of-life management of electric vehicles is the difference between the expected lifetime of the batteries and of the vehicles. The typical ELV-age is about 12 to 16 years [13]. So far, there is no experience with EV battery statistics, but it seems reasonable to assume that at least some of the end-of-life-EV's will contain a battery that still has a functional value (either the original battery or a replace battery). Given the high price of the EV-batteries, a seconduse market may develop. According to the ELV, this second use has to be considered and reported as reuse. Obviously, when these batteries reach their end-of-life, they have to be recycled according to the BD. But when they enter the battery recycling industry as 'stand alone' (not via the ELV compliance schemes), they will not be included in ELV reporting. 
To summarize: although the recycling process of EV batteries in different scenario's would be all the same, the ELV reported recycling rate would be highly dependent on a particular situations. Table 4 shows the results for different scenarios:

- Electric vehicle delivered without battery: battery is assumed to be reused $(100 \%)$

- Electric vehicle delivered with battery, battery materials that are used for energy recovery are not reported in the $\mathrm{BD}$ reporting, resulting in different RE, depending on material choices.

Table 4: different reporting figures for the same

\begin{tabular}{|l|c|c|c|}
\hline \multirow{2}{*}{} & $\begin{array}{c}\text { EV's } \\
\text { delivered } \\
\text { without } \\
\text { battery }\end{array}$ & \multicolumn{2}{c|}{$\begin{array}{c}\text { EV's delivered with } \\
\text { battery, recycled at } \\
\text { Umicore }\end{array}$} \\
\cline { 2 - 4 } & & $\begin{array}{c}\text { steel } \\
\text { casing }\end{array}$ & $\begin{array}{c}\text { synthetic } \\
\text { fibre casing }\end{array}$ \\
\hline $\begin{array}{l}\text { Reuse } \\
\text { rate \% }\end{array}$ & 100 & & \\
\hline $\begin{array}{l}\text { Recycling } \\
\text { rate\% }\end{array}$ & & 60 & 51 \\
\hline
\end{tabular}

Although on member state level, reporting is consolidated for all collected and recycled cars per year, individual car OEM's might have interests to know the specific RE for their segment.

\section{References}

[1] EC Directive 2006/66/EC http://eurlex.europa.eu/LexUriServ/LexUriServ.do?uri=OJ:L:2 006:266:0001:0014:en:PDF accessed on 2013-06-19

[2] QUESTIONS AND ANSWERS ON THE BATTERIES DIRECTIVE (2006/66/EC)

http://ec.europa.eu/environment/waste/batteries/pdf/qa .pdf accessed on 2013-06-19

[3] COMMISSION REGULATION (EU) No 493/2012 of 11 June 2012

http://eur-

lex.europa.eu/LexUriServ/LexUriServ.do?uri=OJ:L:2 012:151:0009:0021:en:PDF accessed on 2013-06-19

[4] European Commission Working Document on Draft Guidelines, 21 June 2013. Document submitted to Stakeholders for consultation

[5] EC DIRECTIVE 2000/53/EC

http://eur-

lex.europa.eu/LexUriServ/LexUriServ.do?uri=CONS

\section{Conclusion}

The Regulation for the recycling efficiency calculation offers a solid basis for the complex mixture of Li-ion battery chemistries, processed together in a robust battery recycling plant of Umicore.

The Umicore process has a theoretical and effective recycling efficiency that is above the EU target of $50 \%$.

A crucial question is whether the current RE-target for Li-ion batteries is an effective qualifier to testify that the $\mathrm{BD}$ targets are met: no dissemination in the environment of hazardous waste and contribution to the resource efficiency targets. It seems that there is not necessarily a correlation between the RE and the environmental and resource efficiency targets. A specific REtarget for Li-ion batteries would be appropriate.

The BD's RE calculation is based on another concept and is much more detailed then the recycling target of the ELV. On the other hand, it doesn't take into account the energy recovery of some of the battery materials. Therefore, consolidation of the BD's RE for batteries in the ELV recycling/recovery rates is not straightforward. It would make sense to consider an (H)EV battery as completely recycled for ELV purposes, if the battery has been recycled in compliancy with the BD.

LEG:2000L0053:20050701:EN:PDF accessed on 201306-19

[6] DIRECTIVE 2012/19/EU of 4 July 2012

http://eur-

lex.europa.eu/LexUriServ/LexUriServ.do?uri=OJ:L:2 012:197:FULL:EN:PDF

\section{[7] COMMISSION DECISION of 1 April}

$2005(2005 / 293 / \mathrm{EC})$

http://eur-

lex.europa.eu/LexUriServ/LexUriServ.do?uri=OJ:L:2005:0

94:0030:0033:EN:PDF accessed on 2013-06-19

[8] Umicore Battery Recycling, http://www.batteryrecycling.umicore.com/UBR/process/ accessed on 2013-06-19

[9] DIRECTIVE 2006/12/EC of 5 April 2006 http://eur-

lex.europa.eu/LexUriServ/LexUriServ.do?uri=OJ: L:2006:114:0009:0021:EN:PDF accessed on 201306-19 
[10] Question for written answer to the Commission Rule 117 Marielle De Sarnez (ALDE) http://www.europarl.europa.eu/sides/getDoc.do? pubRef=$\% 2 \mathrm{f} \% 2 \mathrm{fEP} \% 2 \mathrm{f} \% 2 \mathrm{fTEXT} \% 2 \mathrm{bWQ} \% 2 \mathrm{bE}-2010$ $3855 \% 2 \mathrm{~b} 0 \% 2 \mathrm{bDOC} \% 2 \mathrm{bXML} \% 2 \mathrm{bV} 0 \% 2 \mathrm{f} \% 2 \mathrm{fE}$ $\underline{\text { N\&language }=E N}$ accessed on 2013-06-19

[11] Critical raw materials for the EU, Report of the Ad-hoc Working Group on defining critical raw materials, June 2010

http://ec.europa.eu/enterprise/policies/rawmaterials/files/docs/report_en.pdf accessed on 201306-19

[12] Jean Klein, Eurostat, personal communication, June 19, 2013

[13] Febelauto, Jaarverslag 2012, http://issuu.com/jaarverslagfebelauto/docs/jvs_febelau to_final accessed on 2013-06-19

\section{Authors}

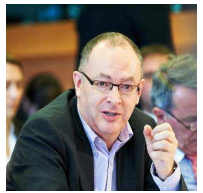

Jan Tytgat obtained a $\mathrm{PhD}$ in Inorganic and Analytical Chemistry from the University of Leuven (Belgium). In 2008, he became General Manager of a new activity for Umicore: Battery Recycling, with focus on recycling of new generation rechargeable batteries. In February 2012, he joined Umicore's Government Affairs team, to develop a long term relation with public authorities on 'cleanmobility' and recycling. 